Cilt / Volume: 2

Sayı / Is sue : 2

Kiş/ Winter 2021

DS e l çu k Ün i versitesi

İslami İlimler Fakültesi Dergisi

\title{
Aşı Karşıtı Tutumların Sosyokültürel ve Dinî Boyutları
}

Araştırma

Research

\section{Talip Demir}

Dr. Öğr. Üyesi, Şırnak Üniversitesi, İlahiyat Fakültesi, Din Sosyolojisi Anabilim Dalı Assistant Professor, Şırnak University, Faculty of Divinity, Department of Sociology of Religion

Şırnak, Türkiye

talipdemir83@gmail.com

https://orcid.org/0000-0003-0030-9481

Yazar

Author

Demir, Talip. “Așı Karşıtı Tutumların Sosyokültürel ve Dinî Boyutları". Tevilat 2/2 (2021), 275-291.

d .) https://doi.org/10.53352/tevilat.1034303 


\section{Aşı Karşıtı Tutumların Sosyokültürel ve Dinî Boyutları}

Hastalıklarla mücadele noktasında tıbbın geliștirdiği en önemli araçlardan biri de aşılamadır. Bu uygulama sayesinde insanlar, daha hastalığa yakalanmadan korunma imkanına kavuşmuş ve böylelikle birçok kişinin hayatı kurtarılabilmiştir. Ne var ki 19. yüzyılın başlarında, ilk aşıların üretilip kitlesel aşılamaya başlanmasından itibaren bu uygulamaya karşı bazı itirazlar dile getirilmiş, bu bağlamda aşı karşıtı tutumları (aşılara yönelik güvensizlik, tereddüt, reddetme) benimseyen sivil toplum örgütleri kurulmuştur. Takip eden yüzyılda da zaman zaman gündeme gelen bu karşıtlık, gelinen noktada dünyanın hemen her ülkesine yayılarak Dünya Sağlık Örgütü tarafından küresel bir sağlık tehdidi olarak ilan edilmiştir. Bu nedenle söz konusu olguyu tanımlamak, tasvir etmek ve bu tür bir olgunun ortaya çlkmasında etkili olan faktörleri belirlemek önem arz etmektedir. Așı karşıtı tutumların ortaya çıkmasını ve yaygınlık kazanmasını etkileyen çok sayıda bireysel, toplumsal ve tarihsel faktör vardır. Başka bir ifadeyle söz konusu olgunun içeriği çok boyutlu bir görünüm arz etmektedir. Çalışmamız konuyu toplumsal boyutlarıyla ele almış ve çalışmada aşıya karşı olumsuz tutumların arkasında yatan sosyokültürel ve dinî faktörlerin ortaya konulması hedeflenmiştir. Bu bağlamda söz konusu tutumların ortaya çıkmasında sağlık kurumlarına ve aşı üreticilerine güvenmeme, aşıların içeriğinde dinen sakıncalı ürünlerin bulunması, yaşamın tıbbîleştirilmesi ve Batı medeniyetine yönelik reaksiyon gibi unsurların rol oynadığı sonucuna ulașılmıștır.

Anahtar Kelimeler: Din Sosyolojisi, Așı Karşıtlı̆̆ı, Toplumsal Güven, Modern Tıp,

\section{Sociocultural and Religious Dimensions of Anti-Vaccination Attitudes}

One of the most important tools developed by medicine in the struggle against diseases is vaccination. By means of this application, people could be protected before they get sick, and so many people's lives can be saved. However, at the beginning of the 19th century, since the first vaccines were produced and mass vaccination started, some objections were expressed against this practice, and in this context, non-governmental organizations that adopted anti-vaccination attitudes (distrust, hesitation, refusal towards vaccines) were established. This opposition, which came to the fore from time to time in the following century, has spread to almost every country in the world at this point and has been declared as a global health threat by the World Health Organization. For this reason, it is important to define and describe the fact and to determine the factors that are effective in the emergence of such fact. There are many individuals, social and historical factors that affect the emergence and prevalence of anti-vaccine attitudes. In other words, the content of the fact presents a multidimensional aspect. Our study dealt with the issue with its social dimensions and aimed to reveal the sociocultural and religious factors behind the negative attitudes towards the vaccines. In this context, it has been concluded that factors such as distrust of health institutions and vaccine companies, the presence of religiously objectionable products in the content of vaccines, the medicalization of life and the reaction against Western civilization play a role in the emergence of these attitudes. 


\section{Giriş}

Hastalıkla ve hastalıklarla öteden beri mücadele eden insanoğlu sağlığına kavuşmak ve hayatta kalmak için çeşitli tedavi metotları geliştirmiştir. Modern tıbbın gelişmesiyle birlikte bu konuda bir hayli yol alan insanlık, geliştirdiği ilaçlar ve teknolojik cihazlar sayesinde birçok hastalığın tedavisinde gözle görülür başarılar elde etmiştir. Üstelik yalnızca hastalığı tedavi etmenin değil, daha hastalık ortaya çıkmadan onu engellemenin yollarını da aramayı ihmal etmemiştir. Bu amaçla ortaya çıkan aşılar, önleyici sağlık hizmetleri kapsamında kullanılan en etkili yöntemlerden biridir.

Așılar bir bütün olarak toplumun sağlığını geliștirmede koruyucu tıbbın ve halk sağlığı uygulamalarının en etkili ögelerinden biridir. Zira așllar insan vücudunun bağıșıklık kazanmasına dair genel kabul gören tıbbî ilkelerin sağlık alanındaki en başarılı uygulaması olarak görülmüştür. Dahası aşılama sadece halk sağlığı alanında değil, bir bütün olarak toplumdaki gelir eşitsizliğinin giderilmesi, sağlık hizmetlerine erișim noktasında adaletin sağlanması, sağlık sistemlerinin alt yapısal olarak güçlendirilmesi gibi alanlarda da önemli sosyoekonomik kazanımlar sağlamaktadır. ${ }^{1}$

Aşıların enfeksiyon hastalıkları ile mücadele hususunda en etkili koruma yöntemi olduğu bilim insanları tarafından yaygın bir kabul görmektedir. Nitekim aşılar sayesinde, Dünya Sağlık Örgütü (DSÖ) ve Hastalık Kontrol ve Korunma Merkezleri (CDC) gibi kuruluşların çeşitli zamanlarda yayımladığı raporlarında da belirtildiği gibi, en azından gelișmiș ülkelerde zaman içinde bir dizi enfeksiyon hastalığı ya tamamen ortadan kaldırılmış ya da hastalığın görülme sıklığında önemli azalmalar kaydedilmiștir. Örneğin çiçek hastalığının dünya üzerinden silinmesi sağlanmış; çocuk felci, kızamıkçık ve difteri gibi bazılarının ise Avrupa kıtası gibi belirli coğrafyalarda ortadan kaldırılması mümkün olmuștur. Dolayısıyla aşılama geçmişten günümüze halk sağlı̆̆ı alanında yaşanan en önemli gelişmelerden biri olarak değerlendirilmektedir. Bu bağlamda aşların, dünyanın birçok yerinde bulaşıcı hastalıkların kontrol altına alınmasını sağlayan hayat kurtarıcı teknolojiler ${ }^{2}$ olduğu ifade edilmiștir.

Öte yandan aşılama, en başarılı halk sağlığı önlemlerinden biri olarak kabul edilmesine rağmen giderek artan sayıda insan tarafından güvensiz ve gereksiz olarak algılanmaktadır. Așı karşıtı tutumlar (aşıya karşı olup reddetme, aşı takvimini geciktirme, aşlların etkinliğinden şüphe duyma ve içeriğine güvenmeme, aşı yaptırmaya direnme) aşı kabul oranlarının düșmesine, așı ile önlenebilir hastalıkların ve salgınların artmasına neden olmaktadır. ${ }^{3}$ Bu nedenle son dönemlerde özellikle Batı dünyasında başlayan ve diğer toplumlara da sirayet eden aşılama karşıtı hareketlerin artışı insan sağlığı ve toplum bağışıklığı açısından ciddi bir tehdit oluşturmaktadır. Örneğin kızamık hastalığı neredeyse

1 Çiğdem Kader, "Aşı Karşıtlığı: Așı Kararsızlığı ve Așı Reddi", ESTÜDAM Halk Sağlığı Dergisi 4/3 (2019), 378.

2 Selim Badur, "Așı Karșıtı Gruplar ve Așılara Karșı Yapılan Haksız Suçlamalar", ANKEM Dergisi 25 (2011), 82; E. Dubé, "Addressing Vaccine Hesitancy: The Crucial Role of Healthcare Providers", Clinical Microbiology and Infection 23/5 (2017).

3 Eve Dubé vd., "Vaccine Hesitancy, Vaccine Refusal and the Anti-Vaccine Movement: İnfluence, İmpact and Implications", Expert Review of Vaccines 14/1 (2015). 
ortadan kaldırılmak üzere iken yeterli bağıșıklık oranı sağlanamadığı için 'geri dönüş' yapan en önemli hastalıklardan biridir. ${ }^{4}$

Gerek bulaşıcı hastalıklara karşı bireysel ve toplumsal korumada gerekse yaşam kalitesini artırma noktasında aşıların etkinliği, önemi ve başarısına dair genel bir kanaat olsa da aşıların etkinliği ve gerekliliği konusundaki şüpheler ile aşıların yol açabileceği zarar olasılığı hakkındaki düşünceler iki yüzyılı aşkın bir süre önce aşıların piyasaya sürülmesinden bu yana var olmuştur. ${ }^{5}$ Zira aşılama, bireylerin vücutlarına bir ilaç veya tıbbî madde enjeksiyonunu onaylamalarını gerektiren fiilî bir müdahale olduğundan hararetli bir muhalefeti de beraberinde getirmiştir. Bu muhalefet ilk aşlarla başlamış, zaman içerisinde devam etmiş ve muhtemelen hiç sona ermeyecek gibi görünmektedir. ${ }^{6} \mathrm{Bu}$ nedenle aşıya ve aşılama faaliyetlerine yönelik olumsuz tutumların arka planında yer alan faktörlerin ortaya konulması son derece önem arz etmektedir.

Aşı karşıtı tutumların ortaya çıkmasını ve gelişmesini etkileyen çok sayıda bireysel, toplumsal ve tarihsel faktör vardır. Başka bir ifadeyle söz konusu olgunun içeriği çok boyutlu ve girift bir yapı arz etmektedir. Bu nedenle çalışmamız konuyu toplumsal boyutlarıyla ele alarak "aşıya karşı olumsuz tutumların arkasında yatan sosyokültürel ve dinî dinamikler nelerdir?" sorusuna odaklanmaktadır. Bu bağlamda çalışmamızın amacı aşı karşıtı tutumların ortaya çıkıp yaygınlaşmasında etkili olan sosyokültürel ve dinî faktörleri ortaya koymaktır.

\section{Tarihsel Arka Plan}

Modern tıbbın hastalıklarla mücadele noktasında geliștirdiği en etkili araçlardan biri olan aşıların kadim dönemlerden itibaren uygulandığına dair çeşitli görüşler ortaya atılmıştır. Buna göre milattan sonraki bin yılda hatta daha da öncesinde aşılama benzeri uygulamaların Çinliler ve Hintliler tarafindan yapıldığına dair çeşitli belgelerin olduğu iddia edilmiștir. Ancak bu konuda elimizde yeterli düzeyde kanıt bulunmamakta, bilinen ilk kanıtlar ise aşılama işlemlerinin 18. yüzyılda başladığını göstermektedir. ${ }^{7}$

Așı fikrinin ilk olarak bir çiftçi olan Benjamin Jesty tarafından 1774 yılında karısı ve iki oğluna yapmış olduğu uygulama ile ortaya çıktığı ifade edilmiştir. Bundan ilham alan Doktor Edward Jenner 1796 yılında inek çiçeği hastalığ geçirenlerin çiçek hastalığından korunduğunu fark etmiş ve inek çiçeği hastalığı geçirmekte olan bir hastadan aldığı sıvı numunesini sağlıklı bir bireye enjekte etmiştir. Nihayetinde yapılan bu işlemin hastaları enfeksiyondan koruduğu sonucuna ulaşmış, sonrasında çok sayıda klinik deney yaparak bu sonuçları dünya ile paylașmıştır. Buradan hareketle herhangi bir sağlıklı kişiye bilinçli olarak inek çiçeği mikrobu verildiğinde, bireyin hastalığa karşı korunduğu

4 Önder Kılıçaslan, "Așı Karşıtlığı Tarihçesi", Güncel Çocuk Sağlığı ve Hastalıkları, ed. Cengiz Yakıncı (Ankara: Akademisyen Yayınevi, 2020), 38.

5 Regina Célia de Menezes Succi, "Vaccine Refusal - What We Need to Know", Jornal de Pediatria 94/6 (2018), 579.

6 Robert M. Wolfe-Lisa K. Sharp, "Anti-vaccinationists: Past and Present", BMJ (Clinical research ed.) 325/7361 (2002), 432.

7 Melike Yavuz, "Așı Karşıtlığının Tarihçesi", Toplum ve Hekim 33/3 (Mayıs-Haziran 2018). 
belirlenmiştir. Bu gelişmeleri takiben 1885 yılında kuduz așısı, 1896 yılında tifo ve kolera aşıları, 1897 yılında ise veba aşısı keşfedilmiştir. 1900'lü yıllardan itibaren de sırasıyla difteri, boğmaca, tetanoz, tüberküloz ve sarıhumma aşıları keşfedilmiștir. ${ }^{8}$

Jenner'in çalışmalarının ardından gerçekleştirilen birçok farklı klinik deney çiçek hastalığına karşı aşılamanın ne derece etkili bir önleyici sağlık hizmeti olduğunu ortaya koymuştur. Öyle ki çiçek aşısı İngiltere'de tüm yeni doğan çocuklar için 1853 'te yasal bir zorunluluk haline getirilmiştir. Söz konusu yasa ilk önce katı bir şekilde uygulanmamış, ancak 1864-68'deki küçük bir salgın sırasında önceki mevzuat sıkılaştırılarak Halk Sağlı̆̆ Kurullarına bunun uygulanmasını sağlama ve buna uymayan ebeveynleri kovuşturma görevi verilmiştir. Bununla birlikte, bu zamana kadar așının ciddi ve bazen ölümcül yan etkileri de bildirilmiştir. 1870'lerin başlarında çeşitli yerlerde aşının etkinliği konusunda şüphe uyandıran salgınların patlak vermesiyle hem tıbbî hem de etik gerekçelerle aşılara karşı bir muhalefet kampanyası büyümeye başlamış ve Aşı Karşıtı Birlikler kurulmuştur. ${ }^{9}$

19. yüzyılın sonlarına doğru Amerika Birleşik Devletleri'nde de aşı karşıtı faaliyetler artmıştır. Yüzyılın başlarında yaygın aşılama çiçek hastalığı salgınlarını içeriyorken 1870'lerde nüfusun duyarlılığı nedeniyle hastalık salgın haline gelmiştir. Bununla birlikte Eyaletler mevcut aşı yasalarını uygulamaya veya yenilerini çıkarmaya çalıştıkça şiddetli aşı karşıtı hareketler ortaya çıkmıștır. 1879'da önde gelen İngiliz așı karşıtı William Tebb'in New York'u ziyaretinden sonra Amerika Așı Karşıtı Derneği kurulmuştur. Ardından 1882'de New England Zorunlu Aşı Karşıtı Birliği ve 1885'te New York City Așı Karşıtı Birliği kurulmuştur. ${ }^{10}$ 19. yüzyılda ortaya çıkan aşı karşıtı hareketlerin arka planına bakıldığında dönemin siyasî/sosyal konjonktürüyle yakın bir ilişkisinin olduğu anlaşılmaktadır. Zira bu dönemde sosyoekonomik düzeyi yüksek olan kesimlere daha güvenli olduğu düşünülen aşıların sağlanması, aşı yaptırmayanlara uygulanan zorlayıcı yaptırımların aristokrat sınıfa uygulanmaması gibi eşitsiz yaklaşımlar özellikle alt sınıfların aşıya karşı direnç göstermesine neden olmuştur. Dolayısıyla aşı karşıtı hareketler aşının kendisinden ziyade bireysel özgürlükler ve toplumsal eşitsizlikler bağlamında gündeme getirilmiştir. ${ }^{11}$

20. yüzyılda aşı kullanımının yaygınlaşmasına rağmen aşılara yönelik muhalefet hiçbir zaman tamamen ortadan kaybolmamış, dünyanın farklı bölgelerinde farklı argümanlarla zaman zaman yeniden alevlenmiştir. Avrupa, Amerika, Avustralya ve Asya gibi dünyanın hemen her kıtasında ortaya çıkan aşı karşıtı gruplar çok sayıda görsel ve basılı yayın yaparak fikirlerini yaymıștır. 1970’li yıllarda ise difteri-tetanoz-boğmaca (DTP) aşısı, suçiçeği aşısından sonra en çok tartışılan ikinci aşı haline gelmiştir. 0 yıllarda bu tartışmalara zemin hazırlayan şey ise 1974'te İngiltere'de yayımlanan bir makaledir. Makalede,

8 Stanley A. Plotkin-Susan L. Plotkin, "The Development of Vaccines: How the Past Led to the Future", Nature Reviews Microbiology 9/12 (2011); Kılıçaslan, "Așı Karşıtlığı Tarihçesi", 26.

9 Stanley Williamson, "Anti-Vaccination Leagues", Archives of Disease in Childhood 59 (1984), 1195.

10 Wolfe-Sharp, "Anti-vaccinationists: Past and Present", 431.

11 Kader, "Așı Karșıtlığı: Așı Kararsızlığı ve Așı Reddi", 380. 
Londra'da bir çocuk hastanesinde 36 çocuk üzerinde araştırmalar yapıldığı ve bu 36 çocuğun 36'sında da DTP aşı uygulaması sonrasındaki ilk 24 saat içinde nörolojik komplikasyonların kümelendiği, bu kümelenmelerin ise tesadüfi değil nedenselliğe bağlı olduğu belirtilerek DTP aşısı hedef gösterilmiştir. Bu makalenin yayınlanması İngiltere'de boğmaca aşılama oranlarının beş yıl içinde \%81'den \%31'e düşmesine neden olarak bir boğmaca salgınına neden olmuş ve ülkeyi zor durumda bırakmıștır. ${ }^{12}$

1998 yılında prestijli bir tıp dergisi olan The Lancet'te Andrew Wakefield tarafından aşı karşıtı hareketlerin alevlenmesine sebep olan bir çalışma yayımlanmıştır. Bu çalışmasında Wakefield 12 çocuk ve genç erişkin üzerinde yaptığı araştırmada kızamık, kabakulak ve kızamıkçık (KKK) aşısı ile otizm arasında pozitif bir ilișki olduğunu öne sürmüștür. Daha sonrasında yayımlanan birçok çalışma KKK aşısı ve otizm arasında nedensel bir ilişki olduğunu reddetmiş ve Wakefield'in makalesi yayından kaldırılmış ${ }^{13}$ olsa da söz konusu çalışma aşıların güvenliğine dair ciddi endişelerin yayılmasına sebebiyet vermiștir.

1990’lı yıllardan itibaren dünya genelinde başlayan ve hızla yayılma eğilimi gösteren aşı karşıtı tutumların toplum sağlığı için tehlikeli boyutlara ulaştığı ifade edilmiştir. Nitekim 2019'da DSÖ, çözüme kavuşturmayı planladığı 10 küresel sağlık sorunu arasında aşı karşıtlığına da yer vermiştir. Diğer yandan Türkiye'de 2010'lu yıllardan itibaren nadir de olsa görünen aşı karşıtı tutumlar hem küresel iletişim araçlarının hem de 2015 yılında yaşanan bir gelişmenin etkisiyle giderek artma eğilimine girmiștir. 2015'te bir savcının ikiz bebeklerine aşı yaptırmaması üzerine Aile, Sağlık ve Sosyal İl Müdürlüğü çocuklar için sağlık önlemi davası açmıştır. İkizlerin babası bireysel hak ihlali ve onam alınma zorunluluğu getirilmesi isteği ile karşı dava açmış ve bu davayı kazanmıştır. Gazetelerde ve sosyal medyada 'İkiz bebeklerine aşı yaptırmayan savcının hukuk zaferi' olarak yansıtılan bu durumun ardından birçok grup aşı karşıtı söylemlerini artırmıştır. Bu süreç öylesine etkili olmuştur ki Türkiye'de 2015 yılında aşıyı reddeden aile sayısı 5091 iken bu sayı 2016 yılında 12000'i, 2017 yılında ise 23000'i aşmıştır. ${ }^{14}$

İlk aşıların üretilmesiyle eş zamanlı ortaya çıkan aşı karşıtı tutumlar günümüzde giderek artan bir şekilde etkisini sürdürmektedir. Özellikle 2019'da Çin'in Vuhan eyaletinde ortaya çıkan ve sonrasında DSÖ tarafından pandemi ilan edilen Covid-19 salgını, söz konusu karşıt tutumların ve hareketlerin daha da radikalleşmesine ve görünür olmasına neden olmuştur. Bu süreçte Covid-19 hastalığına karşı üretilen aşılara ve küresel çapta başlatılan aşı seferberliğine yönelik dünyanın hemen her yerinden tepkiler gelmiştir/gelmeye devam etmektedir. Dolayısıyla bugün yaşanmakta olan aşı karşıtı

12 Kılıçaslan, "Aşı Karşıtlı̆̆ı Tarihçesi", 30.

13 Lauren R. Kolodziejski, "Harms of Hedging in Scientific Discourse: Andrew Wakefield and the Origins of the Autism Vaccine Controversy", Technical Communication Quarterly 23/3 (2014); Kılıçaslan, "Aşı Karşıtlığı Tarihçesi", 31.

14 Kader, "Așı Karșıtlığı: Așı Kararsızlığı ve Așı Reddi", 386; Hayrunnisa Bekis Bozkurt, "Așı Reddine Genel Bir Bakıș ve Literatürün Gözden Geçirilmesi", Kafkas Tıp Bilimleri Dergisi 8/1 (2018); Ayırca bk. Hürriyet Gazetesi "İkiz bebeklerine așı yaptırmayan savcının hukuk zaferi" (28 Kasım 2021) 
hareketlerin/tutumların aslında yeni bir olgu olmadığı, bilakis iki yüzyıldır devam etmekte olan bir karşı-oluş tavrının daha da kitleselleşerek yeni bir forma bürünmüş hali olduğu söylenebilir.

Bugün dünya çapında yaygınlașmaya bașlayan tablo hemen her ülkede aşılara karşı yükselen bir şüphecilik dalgasının ortaya çıkmasıdır. Konuyla ilgili yapılan bir dizi çalışma, aşıyla ilgili endişelerin ve olumsuz tutumların ebeveynler arasında, özellikle çocukluk çağı aşılarında, oldukça yaygın olduğunu ve hatta çocuklarını aşılayanlar arasında bile var olduğunu göstermektedir. Aşıların güvenliğini ve etkinliğini gösteren çok sayıda bilimsel kanıta rağmen aşı tereddüt ve ret oranları artmaya devam etmektedir. Örneğin son yıllarda birçok ülkede baş gösteren boğmaca ve kızamık salgınları, aşı tereddüt ve reddinin potansiyel yıkıcı etkilerini göstermesi bakımından dikkat çekmektedir. ${ }^{15}$

\section{Sosyokültürel Etkiler}

İnsan ilişkilerinin karmaşık yapısı, bu ilişkiler neticesinde ortaya çıkan toplumsal olguların anlaşılmasında birtakım güçlükler doğurmaktadır. Bu durumu aşmaya çalışan sosyal bilimciler ilgilendikleri konuyu çeşitli başlıklar altında analitik bir yöntemle sınıflandırmaya çalışmışlardır. Söz konusu güçlük aşıya yönelik olumsuz tutumların analizi noktasında da karşımıza çıkmaktadır. $\mathrm{Bu}$ nedenle 2012 yılında kurulan bir çalışma grubunun temel görevi bu tür olumsuz tutumların öncelikle tanımını yaparak kapsamını belirlemek ve aşıyı kabul ya reddetme kararını etkileyen faktörleri kategorize etmek için bir model geliştirmek olarak belirlenmiştir. Buna göre bu faktörler üç kategoride toplanmıştır: bağlamsal etkiler, bireysel/kolektif etki, aşıya/aşılamaya özgü etkiler. Bu çerçevede söz konusu olumsuz tutumları etkileyen sosyokültürel faktörler bağlamsal etkiler başlığı altında sıralanmıştır. ${ }^{16}$ Burada ele alacağımız sosyokültürel faktörler ise ailelerin ya da bireylerin sosyodemografik nitelikleri, sosyoekonomik düzeyleri ve güven algısını içermektedir.

Ailelerin/ebeveynlerin sosyodemografik özellikleri kendilerine ya da çocuklarına aşı yaptırma konusundaki karar sürecini etkilemektedir. Örneğin ailenin çocuk sayısı, ebeveynlerin eğitim ve gelir düzeyleri, ebeveynlerin aşı konusundaki düşünce ve yaklaşımları, ailenin sosyal güvenceye sahip olup olmaması gibi unsurların aşılanma oranlarını etkilediği belirtilmektedir. ${ }^{17}$ Aşı karşıtı tutumlar üzerine yapılan uygulamalı bir çalışmaya göre katılımcıların eșlerinin eğitim durumu da değerlendirilmeye alınmıș, buna göre așı reddi grubundaki ailelerin \%59'unda en az bir lisans ve üzeri eğitim durumuna sahip ebeveyn bulunurken kontrol grubunda en az bir ebeveynin lisans ve üzeri eğitim durumuna sahip olduğu aile oranının \%37,8 olduğu belirtilmiștir. Hem çalışmaya katılan kişinin eğitim durumu hem de ailesindeki toplam eğitim durumu yönünden aşıyı reddeden grubun eğitim düzeyinin diğer gruba göre daha yüksek olduğu ifade edilmiştir. Çalışmadan elde edilen bulgular Türkiye'de

15 Julie A. Boom-Rachel M. Cunningham, Understanding and Managing Vaccine Concerns (Switzerland: Springer, 2014), 11.

16 Noni E. MacDonald, "Vaccine Hesitancy: Definition, Scope and Determinants", Vaccine 33/34 (2015).

17 Neslihan Argüt vd., "Așı Kabulünü Etkileyen Faktörler", Cocuk Dergisi 16/1-2 (2016), 18. 
aşı karşıtı tutumların yüksek eğitim seviyesine sahip kişilerde daha fazla olduğunu göstermektedir. ${ }^{18}$

Konuya dair yapılan bir diğer alan çalıșmasında da toplumdaki bazı kesimlerin aşı karşıtlığının nedenleri incelenmiştir. Bu çalışmada eğitim düzeyi yüksek her 10 kadından 3 'ünün aşılamanın yararlı olduğunu düşünmediği ve bu oranın düşük eğitimli gruba göre 10 kat daha fazla olduğu tespit edilmiştir. Başka bir ifadeyle aşı olmayı reddeden veya aşıya yönelik tereddüt yaşayanların daha çok sosyoekonomik ve gelir düzeyi yüksek genç kadınlar olduğu belirlenmiştir. Söz konusu bulgular, Türkiye açısından düşünüldügünnde, 2010 yılı öncesinde düşük eğitim düzeyinin aşıya ulaşma olanağını azalttığını, bunun da aşı oranını düşürdügünü; diğer yandan son zamanlarda gelişen aşı karşıtı tutumların ise așlara kolay erișimi olan eğitimli bireyler arasında yaygınlaștığını ${ }^{19}$ göstermektedir. Benzer şekilde Kore'de ${ }^{20}$ ve İsveç'te ${ }^{21}$ yapılan çalışmalarda da aşıya karşı olumsuz tutum içinde olan kişilerin eğitim seviyelerinin yüksek olduğu tespit edilmiștir.

Geçmişten günümüze aşılara yönelik endişelerin ya da karşıt tavırların altında yatan en temel faktörlerden biri de algılanan güvenlik eksikliğidir. Üstelik bu tür endişelerin potansiyel varlığı yaşanan bazı olaylar neticesinde gün yüzüne çıkmıştır, denilebilir. Zira aşıların güvensiz olabileceği fikri, çocuk felci aşısının üretimi sırasında somut bir karșılık bulabilmiştir. Bu bağlamda en önemli halk sağlığı başarılarından birinin hemen ardından ABD'deki en kötü biyolojik trajedilerden biri olan Nisan 1955 'te Cutter Olayı meydana gelmiştir. Cutter Laboratuvarı, California'da bulunan ve Jonas Salk'ın çocuk felci aşısını üretme ruhsatına sahip küçük bir ilaç şirketidir. Yıllarca süren bilimsel çabalardan sonra Dr. Salk inaktive edilmiş bir çocuk felci aşısı geliştirmiştir. Aşının seri üretimine geçiş sırasında Cutter laboratuvarı polio virüsünün tamamen inaktive olmadığı, daha ziyade canlı, aktif polio-virüs içerdiği birkaç aşıyı uygulama için serbest bırakmıștır. 120 bin çocuk daha sonra așılamanın ardından canlı, aktif polio virüsüne maruz kalmıştır. Aşı olanların 70 bini hafif çocuk felci geçirmiş, 200'ü kalıcı olarak felç olmuş ve 10'u da ölmüştür. Şirketin hatası, ABD tarihindeki en kötü farmakolojik felaketlerden biriyle sonuçlanarak ilaç endüstrisine olan güvensizliğin temellerini atmıștır. ${ }^{22}$

Aşıların içeriğine ya da ilaç firmalarına duyulan güven eksikliği yapılan birçok çalışma ile ortaya konulmuştur. Bu bağlamda 67 ülkede yürütülen önemli bir araştırmanın sonuçları aşılara yönelik genel tutumların olumlu olmasına rağmen aşıya olan güvenin kırılgan olduğunu göstermiştir. Zira aşıların önemine inanan katılımcıların önemli bir kısmının aşı güvenliğine karşı olumsuz tutumlar

18 Muhammet Hasar vd., "Așı Reddi Nedenleri ve Așılar Hakkındaki Görüşler", Cukurova Medical Journal 46/1 (2021).

19 Gökmen Özceylan vd., "Vaccine Rejection and Hesitation in Turkey", Human Vaccines \& Immunotherapeutics 16/5 (2020).

20 Kyujin Chang-Soon Young Lee, "Why Do Some Korean Parents Hesitate to Vaccinate Their Children?", Epidemiology and Health 41 (2019).

21 Emma Byström vd., "Confidence in the National Immunization Program among Parents in Sweden 2016 - A cross-Sectional Survey", Vaccine 38/22 (2020).

22 Boom-Cunningham, Understanding and Managing Vaccine Concerns, 5; Michael Fitzpatrick, "The Cutter Incident: How America's First Polio Vaccine Led to a Growing Vaccine Crisis", Journal of the Royal Society of Medicine 99/3 (2006). 
beslediği tespit edilmiştir. Nitekim Fransa'daki katılımcıların \%41'i așıların güvenli olduğuna inanmadığını belirtmiş, aşı güvenliğine en yüksek düzeyde güvensizliğin Avrupa bölgesinde olduğu ${ }^{23}$ ifade edilmiştir. Benzer şekilde Türkiye'de yapılan bir saha çalışmasında da çarpıcı bulgular elde edilmiştir. Buna göre çalışmaya katılan ebeveynlerin \%96,7'si aşıyı reddetmesinin en önemli sebebinin "Așlların güvenli olduğunu düşünmeme/yan etkileri hakkında endișe sahibi olma" olduğunu ifade etmiștir. ${ }^{24}$

Avrupa'da 2004 ve 2014 yılları arasında aşılara yönelik risk algılarını belirlemek için sistematik bir literatür taraması kapsamında konuyla ilgili yapılmış 145 çalışma incelenmiştir. Buna göre tüm ülkelerde ve aşılarda en büyük endişe alanının aşı güvenliği olduğu ve insanların genellikle aşının risklerinin yararlarından daha fazla olduğuna inandıkları tespit edilmiştir. Ayrıca aşının güvenliğine ilişkin belirsizliğin yanı sıra tüm aşılar için söz konusu olan daha genel korkuların varlığı da tespit edilmiştir. Belirsizlik sorunları aşının güvenliği hakkında üretilen bilgilere duyulan güvensizlik gibi farklı bir zorluğu da ortaya çıkarmaktadır. ${ }^{25}$

Günümüz toplumunun en temel niteliklerinden biri olan bilginin hızlı dağıtımı ebeveynlerin aşılara, aşı sağlayıcılarına ve sağlık sistemine olan güvenini zedeleyebilecek çok sayıda tutarsız bilgiye ulaşmasını kolaylaştırmaktadır. Güven konusu, literatürde aşı-güven boşluğu olarak tanımlanmıştır. Bu noktada insanların bir bireye ya da kuruma olan güveni bireylerin tutumlarını doğrudan etkilemektedir. Nitekim ilaç endüstrisi, hükümet ya da sağlık hizmeti sağlayıcısı gibi bilgi kaynaklarının güvenilirliği, buralardan elde edilen bilgilerin güvenilirliğini etkilemektedir. Örneğin, bazı araştırmalarda kişilerin ilaç şirketlerine şüpheyle bakarak aşıları güvenlik veya gerçek ihtiyaç pahasına kâr sağlamak için tasarlanmıș bir ürün olarak gördükleri tespit edilmiştir. Buna ek olarak bu grupta yer alan kişilerin bazılarının "doğal" ürünleri ve alternatif tıbbı benimsediği, bu nedenle bağıșıklık sistemini güçlendirmenin "doğal olmayan" bir yolu olarak kabul edilebilecek aşılar da dahil olmak üzere birçok tıbbî müdahaleye güvenmediği26 ifade edilmiştir. Dolayısıyla aşı karşıtı tutumlar modern tıp uygulamalarına karşı bir tavır olmakla birlikte küresel șirketlerin așı üzerinden elde ettikleri ranta karșı bir başkaldırma niteliği de taşımaktadır. ${ }^{27}$

Son otuz yıldır giderek artan bir şekilde yaygınlaşan aşı karşıtı tutumların daha büyük bir sosyolojik sürecin tezahürü olduğu söylenebilir. Zira gelinen noktada sadece aşılar değil bir bütün olarak bilimin yararı ve tıp otoritelerinin güvenilirliği sorgulanır hale gelmiștir. Yeni onaylanan ve așılama programlarına dâhil edilen așıların sayısının artması da ailelerin aşıların gerekliliği ve

23 Ohid Yaqub vd., "Attitudes to Vaccination: A Critical Review", Social Science \& Medicine 112/2014).

24 Hasar vd., "Așı Reddi Nedenleri ve Așılar Hakkındaki Görüșler".

25 Emilie Karafillakis-Heidi J. Larson, "The Benefit of the Doubt or Doubts Over Benefits? A Systematic Literature Review of Perceived Risks of Vaccines in European Populations", Vaccine $35 / 37$ (2017).

26 Lori A. Kestenbaum-Kristen A. Feemster, "Identifying and Addressing Vaccine Hesitancy", Pediatric Annals 44/4 (2015).

27 Talip Yiğit vd., "Așı Karşıtlığı ve Fikri Gelișimi", International Journal of Social Humanities Sciences Research (JSHSR) 7/53 (2020), 1260. 
güvenliliğine dair endișelerinin büyümesinde rol oynayabilmektedir. Bazı yeni aşıların aileler tarafından düşük tehlikeli olarak algılanan bazı hastalıkları önlemeye yönelik olması genel olarak bilime özelde ise tıp bilimine duyulan güvenin zedelenmesine yol açabilmektedir. ${ }^{28} \mathrm{Bu}$ bağlamda gündeme getirilen postmodern tıp paradigması, bilimin ve otoritenin meşruiyetini sorgulayarak hastaların daha fazla güce sahip olma ihtiyacını vurgulamaktadır. Dahası bu paradigma, gücün doktorlardan hastalara geçtiği, bilimin meşruiyetinin sorgulandığı ve uzmanlığın yeniden tanımlandığı yeni bir sağlık anlayışını temsil etmektedir. $\mathrm{Bu}$ durum aşı karşıtı grupların mesajlarını etkili bir şekilde yayabilecekleri sosyolojik bir zemin sağlamaktadır. ${ }^{29}$

Buraya kadar ifade edilenler toplumda bir bütün olarak sağlık ya da tıp kurumuna duyulan güvensizliği yansıtmaktadır. Bu güvensizliğin ilk kaynağı ilaç endüstrisinin kâr hırsıyla hareket eden kapitalist sistemin bir parçası haline gelerek sağlığın metalaştırıldığına dair oluşan algıdır. Bu algı yalnızca aşıların dağıtımı ve uygulanmasında değil diğer birçok ilacın da aynı şekilde şüpheyle karşılanmasına zemin hazırlamaktadır. Modern tıbbın en etkili silahları olan ilaçlara duyulan güvenin azalması bir kurum olarak tıbbın güven kaybetmesini ve tıp uygulamalarına yönelik bir tepkiyi de beraberinde getirmektedir. Ancak modern tıbba karşı gelişen bu olumsuz algının yegâne sebebi ilaç endüstrisi değildir. Bunun yanında özellikle 20. yüzyılın sonlarından itibaren modern tıbbın etkisinin artmasıyla beraber bir bütün olarak sosyal hayatın şekillenmesinde tıbbın oynadığı rolün artmış olması da önemli bir faktördür. "Tıbbîleștirme"30 olarak adlandırılan bu süreç zarfında tıbbın giderek otoritesini artırdığı ve neredeyse kutsallık kazandığı ${ }^{31}$ ifade edilmiştir. Dolayısıyla aşılara karşı ortaya çıkan olumsuz tavırların arka planında, yaşamın aşırı derecede tıbbî hale getirilmiş olmasına karşı gösterilen toplumsal bir tepkinin olduğu söylenebilir.

Așı karşıtlığı ya da tereddüdü üzerine yapılan bazı saha çalıșmalarında yukarıda ifade edilen güvensizliğin bu süreçte oldukça belirgin olduğu ortaya konulmuştur. Örneğin Türkiye'de yapılan bir çalışmada aşı karşıtlığının nedenleri arasında en sık rastlanan nedenin așı firmalarına güven duyulmaması olduğu tespit edilmiştir. Bu bağlamda aşılamanın yararsız olduğunu düșünen katılımcıların \%50'si aşı şirketlerine güvenmediğini belirtmiştir. Buna ek olarak așıya karşı olumsuz tavır almanın en yaygın ikinci nedeninin, aşıların zararlı olduğuna dair sosyal medyada yer alan bilgiler olduğu ifade edilmiştir. Çalışmaya katılan kişilerin \%25'i bu tür bilgileri sosyal medyadan edindiğini belirtmiștir. ${ }^{32}$ Gerçekten de sosyal medyanın aşı karşıtı tutumların yayılmasında son derece etkili bir araç olduğu birçok bilimsel çalışma tarafından ifade edilmektedir. ABD ve İngiltere gibi birçok gelişmiş ülkede ortaya çıkan aşı karşıtı hareketlere

28 Ahmet Alp Aker, "Așı Karşıtlığı", Toplum ve Hekim 33/3 (Mayıs-haziran 2018), 178.

29 Anna Kata, "Anti-Vaccine Activists, Web 2.0, and the Postmodern Paradigm - An Overview of Tactics and Tropes Used Online by the Anti-Vaccination Movement", Vaccine 30/25 (2012).

30 Kavramla ilgili detaylı bilgi için bk. Deniz Sezgin, Tıbbileştirilen Yaşam Bireyselleștirilen Sağlık (İstanbul: Ayrıntı Yayınları, 2011); Aynur Toraman-Ramazan Erdem, "Kavramsal Açıdan Tıbbileştirme", Hacettepe Sağlık İdaresi Dergisi 19/4 (Aralık 2016).

31 Talip Demir, "Tıbbın Kestiği Parmak Acımaz: Seküler Tıbbın Kutsallașması", Bozok Üniversitesi İlahiyat Fakültesi Dergisi [BOZIFDER] 14/14 (2018).

32 Özceylan vd., "Vaccine Rejection and Hesitation in Turkey", 1038. 
bakıldığında sosyal medyanın aşı korkularını canlı tutmada nasıl bir rol oynadığı daha net anlaşılmaktadır. Nitekim birçok gelişmiş ülkede boğmaca vaka sayılarına bakan araştırmacılar, aşı güvenliği konusundaki tartışmalar (aktif olarak dolaşımda olan hikayeler, mitler, söylentiler nedeniyle) aşılama programlarına katılımın azaldığını fark etmiştir. ${ }^{33}$

21. yüzyılın en etkin iletişim unsuru olarak ortaya çıkan sosyal medya olgusu, içeriğinde yer alan bilgilerin doğasına ilişkin özgün tanımlamaları da beraberinde getirmiștir. Sanal platformlarda üretilen bilginin yapısını tasvir etmek amacıyla üretilen kavramlardan biri de post-truth kavramıdır. Bu kavram "tam olarak gerçeği yansıtmamakla birlikte yalan da denemeyecek muğlak ifadelerden oluşan üçüncü bir kategori” şeklinde açlklanmakta ve bu kategori için zenginleştirilmiş gerçek, neo-gerçek, sunî gerçek ve hafif gerçek gibi nitelemeler yapılmaktadır. Așıların güvenliği konusunda sosyal medyada yer alan tartışmalar, post-truth kavramının nitelikleriyle örtüşür biçimde, bilimsel doğruluğu kanıtlanmış verilerden ziyade daha az kanıta dayanan ve daha ziyade komplo teorisi olarak nitelendirilebilecek bilgileri savunan kitleler yaratmaktadır. Bu bağlamda yapılan bir araştırmada sosyal medyada yer alan aşı karşıtı grupların kurucularının ve üyelerinin, așı karşıtlıklarını temelde iki gerekçeye dayandırdıkları tespit edilmiştir. Her ikisi de birbiriyle doğrudan ilişkili olan bu iki gerekçe, aşıların hastalıklara ve ölümlere yol açtığı ve aşılama uygulamasının arkasında küresel güçlerin gizli hedeflerinin olduğudur. Buna göre așı karșıtı iddiaların toplumda karşılık bularak așılara ve modern tıbba şüpheyle yaklaşma tutumunun oluşmasında sosyal medyanın büyük bir etkisi olduğu açıkça gözlenmektedir. Zira sosyal medya kendine özgü etkileşimsel yapısıyla özellikle gizli, sır, komplo, skandal vb. olarak nitelendirilebilecek içerikteki bilgilerin sınırsız ve kontrolsüz bir şekilde paylașılabildiği bir platformdur. $^{34}$

Öte yandan sağlık çalıșanları genellikle hastaları için așıyla ilgili en güvenilir bilgi kaynağı olarak kabul edilmektedir. Bununla birlikte bazı veriler sağlık çalışanları arasında bile aşı konusunda tereddütlü olanların bulunduğunu göstermektedir. $\mathrm{Bu}$ bağlamda yapılan bir çalışma, sağlık çalışanlarının aşılamayla ilgili endișelerini araștırmak için Hırvatistan, Fransa, Yunanistan ve Romanya'daki aşı sağlayıcılarıyla 65 yarı-yapılandırılmış görüşmeden oluşmaktadır. Buradan elde edilen bulgular dört ülkede de aşı sağlayıcılar arasında așı tereddüdünün mevcut olduğunu ortaya koymuștur. Tüm ülkelerdeki en önemli endişe kaynağının ise aşıların yan etkileri konusunda olduğu saptanmıştır. Ayrıca toplumun sağlık görevlilerine yüksek düzeyde güven duymasına rağmen sağlık çalışanları arasında özellikle finansal çıkarlar nedeniyle ilaç şirketlerine yönelik güçlü bir güvensizliğin de söz konusu olduğu ifade edilmiştir. ${ }^{35}$ Dolayısıyla aşılara karşı olumlu ya da olumsuz bütün tutumların oluşmasında toplumsal güven algısının başat bir etkisinin olduğu

33 Eve Dubé vd., "Vaccine Hesitancy: An Overview", Human vaccines \& immunotherapeutics 9/8 (2013), 1765-1766.

34 Nilgün Sofuoğlu Kılıç, "Post-Truth Cağda Așı Karșıtlı̆̆ı", Türk İslâm Medeniyeti Akademik Araștırmalar Dergisi 16/31 (Şubat 2021), 113-114.

35 Emilie Karafillakis vd., "Vaccine Hesitancy Among Healthcare Workers in Europe: A Qualitative Study", Vaccine 34/41 (2016). 
söylenebilir. Toplumsal kurumlara ya da toplumda ön plana çıkan kanaat önderlerine duyulan güven, bireysel karar alma sürecinde etkin bir rol oynamaktadır. Nitekim Nijerya'da yapılan bir çalışmada aşılara karşı duyulan kaygıları gidermede dinî ve geleneksel liderlerin son derece etkili olduğu vurgulanmıştır. ${ }^{36}$

\section{Dinî Boyut}

Toplumsal yaşamın oluşumunda ve devamında öteden beri etkin bir rol oynayan din gerek bireysel bir referans kaynağı gerekse toplumu organize eden bir kurum olarak insan hayatında daima var olagelmiştir. Öyle ki insanlar gündelik yaşamda aldıkları bazı kararları dinî referanslarla açıklamaya ya da bunlar vasıtasıyla yaşamlarına şekillendirmeye çalıșmışlardır. Söz konusu etki hayatın hemen her alanında görülebildiği gibi bireylerin genel olarak hastalığa, sağlığa ve tedaviye yönelik bakıș açılarında da açığa çıkmıștır. Nitekim yakın zamanlarda Güneydoğu Avrupa'da çocuklukta aşı reddi ve tereddütünün yaygınlığı ve bağlantıları üzerine yapılan sistematik bir alan araştırmasında dindarlık düzeyinin așılamayı reddetme ihtimalini artırdığı tespit edilmiştir. ${ }^{37}$

Tarihsel sürece bakıldığında aşı uygulamasına dinî gerekçelerle karşı çıkışların, aşının keşfedilip yaygınlaşmasından çok daha önce, 18. yüzyılın ortalarından sonra ortaya çıktığı anlaşılmaktadır. Nitekim James Kirkpatrick'in 1761 tarihli The Analysis of Inoculation adlı eserinde yapılan uygulamaların Tanrı'nın iradesinin bariz şekilde engellenmesi olarak algılandığı ifade edilmektedir. Teolojik otoritelerin uygulamaya karşı muhalefetlerinin ise İncil'deki bazı ayetlerin yorumuna dayandırıldığı görülmektedir. Buna göre Tanrı'nın onaylanan davranışları ödüllendirerek ve onaylanmayan davranışları ağır bir şekilde cezalandırarak çalıştığı, yanlış eylemler için birçok acıdan birinin veba olacağı, bu nedenle insanların başlarına gelenleri kabul etmeleri gerektiği düşünülmüştür. Çünkü bunlar Tanrı tarafından kendilerine verilmektedir ve böyle bir kararlılığa direnmek Tanrı'dan yüz çevirmektir. Bu nedenle, kiși așı yaptırarak kendini hak edilmiş bir beladan korumaya çalışırken Tanrı'nın yargılama adaletine güvenmediğini göstermiş olmaktadır. Buna ek olarak aşllama bir çeşit intihar olarak kabul edilmiş, cehenneme giden dördüncü yol olarak görülmüştür. Zira az da olsa aşıyı yaptıran insanların bir kısmı öldügüne göre, kişinin kendini bu riske gönüllü olarak maruz bırakmasının kişisel bir intihar girișiminde bulunmak olduğu sonucuna ulașılmıștır. Bu durumun Tanrı'nın iradesine aykırı olduğundan yasaklanması gerektiği belirtilmiștir. ${ }^{38}$

Aşı uygulamasına teolojik gerekçelerle karşı çıkış Edward Jenner'in 1796'da çiçek aşısını keşfetmesiyle birlikte daha yüksek sesle dile getirilmeye başlanmıștır. Bu tepki aslında hastalıklara yüklenen anlamla doğrudan ilintilidir.

36 Sebastian Taylor vd., "Understanding Vaccine Hesitancy in Polio Eradication in Northern Nigeria", Vaccine 35/47 (2017).

37 Anja Repalust vd., "Childhood Vaccine Refusal and Hesitancy Intentions in Croatia: Insights from a Population-Based Study", Psychol Health \& Medicine 22/9 (2017).

38 R. E. Spier, "Perception of Risk of Vaccine Adverse Events: A Historical Perspective", Vaccine 20 (2002), 79-80. 
Zira hastalıklar Tanrı'nın gazabı olarak görüldügüünden ${ }^{39}$ aşı yaptırmak Tanrı'nın iradesine meydan okumak olarak anlaşılmıştır. İlerleyen süreçte Amerika Birleşik Devletleri'nde birkaç din adamı ve dindar doktor tarafından 1879'da Aşı Karşıtlığı Derneği kurulmuştur.40

Așıya yönelik dinî kaygıların tedavi yöntemlerine ilişkin birtakım teolojik argümanlarla yakından ilgisi olduğu görülmektedir. Nitekim 1879'da Mary Baker Eddy tarafindan Boston'da kurulan First Church of Christ, Scientist'in üyeleri açısından hastalıkların mânevî tecrübeler yoluyla iyileştirilmesi temel bir ilke olarak benimsenmiștir. Buna göre hastalık aslında Tanrı'nın mükemmelliğini örtmeye çalışan şeytanın yalanlarından başka bir şey değildir. $\mathrm{Bu}$ nedenle hastalığın ancak ve ancak hastalığın gerçekliğini reddeden dua ile iyileștirilebileceği ya da önlenebileceğine inanılmıştır. Nitekim bu grubun mensupları hastalıklar için tıbbî yardımın bir kısmını veya tamamını reddederek bağıșıklama programından dinî muafiyet için hükümetlere baskı yapmıştır. Buna ek olarak zaman içinde tıbbî bakımdan aktif olarak kaçınıp yalnızca inanç yoluyla iyileşmeye odaklanan inançlara sahip birkaç küçük Hıristiyan mezhebi de ortaya çlkmıștır. ${ }^{41}$

Aşılamaya dinî gerekçelerle karşı çıkışın diğer bir boyutu da aşıların üretimi sırasında kullanılan maddelerle ilgilidir. Başka bir ifadeyle aşıların içeriğindeki bazı maddeler dinen sakıncalı olarak görüldüğü için aşılamaya karşı çıkılmıştır. Nitekim 2014'te Amerika Birleşik Devletleri'nde aşıyı reddeden kişiler arasında kızamık vakalarında bir artıș yașanmıștır. Topluluklar ve bireyler bașta dinî ve felsefi gerekçelerle așı yaptırmayı reddetmiștir. Buradaki itirazlar çoğunlukla kombine aşı ürünlerinin kızamıkçık bileșeninde kullanılan kürtajlı insan fetüsü dokusunun ve aşı üretiminde kullanılan hayvansal kaynaklı jelatinlerin kullanımına odaklanmaktadır. ${ }^{42}$ Benzer șekilde Türkiye'de yakın zamanda yapılan bir çalışmada aşıyı reddeden katılımcıların büyük çoğunluğu (\%64) aşıların dinen sakıncalı olduğunu, içerisinde domuz yağı ve yine dinen kullanılması yasak olan içerikler olduğunu belirtmiştir. ${ }^{43}$

Aşıların içeriğinde domuz ürünleri gibi helal olmayan ürünlerin de bulunduğuna dair inanç gerçekten de oldukça etkili olmuş ve aşılama programlarını sekteye uğratmıștır. Öyle ki dinen mubah olmayan herhangi bir maddenin (örneğin domuz jelatini) aşllara veya diğer farmakolojik ürünlere katılmış olması konusunda bazı bilimsel toplantılar yapılmıştır. Bu bağlamda DSÖ, 1995 yılında Kuveyt'te düzenlenen ve "Yiyeceklerde ve ilaçlarda fikhî olarak haram veya necis kabul edilen maddeler" konulu seminerde varılan kararı tüm dünyaya duyurmuştur: "Bir maddenin farklı özellikleri olan bir başka madde

39 Hastalıkların Tanrı'nın gazabı olarak anlaşılması ve yorumlanması hakkında detaylı bilgi için bk. Talip Demir, Din ve Tıp: Sekülerleşme Perspektifinden Bir Yaklaşım (İstanbul: Muhayyel Yayıncılık, 2020), 188-199.

40 John D. Grabenstein, "What the World's Religions Teach, Applied to Vaccines and Immune Globulins", Vaccine 31/16 (2013), 2012.

41 Grabenstein, "What the World's Religions Teach, Applied to Vaccines and Immune Globulins", 2016.

42 Eric Wombwell vd., "Religious Barriers to Measles Vaccination", Journal of Community Health $40 / 3(2015)$.

43 Erhan Aygün-Hasan Said Tortop, "Ebeveynlerin Așı Tereddüt Düzeylerinin ve Karşıtlık Nedenlerinin İncelenmesi", Güncel Pediatri 18/3 (2020). 
haline geçmesi anlamına gelen dönüşüm, fıkhî olarak saf olmayan veya temiz ortamlarda bulunmayan maddelerin saf maddelere dönüşmesi ve yasaklanmış maddelerin meşrû ve izin verilir maddelere değişimidir. Buna göre fikhî açıdan necis bir hayvanın kemik, deri ve dokularından dönüşümle elde edilen jelatinin yenmesi mubahtır". ${ }^{44} \mathrm{Bu}$ tür açıklamalara rağmen aşıların içeriğine yönelik dinî çekinceler ortadan kalkmamıştır. Zira yakın zamanda Türkiye'nin çeşitli illerinde yaşayan ve aşı yaptırmayan ailelerle yapılan bir araştırmada kendisini dindarmuhafazakâr olarak tanımlayan kişilerin büyük çoğunluğu "dinî inancım gereği aşı olmuyorum" ifadesini kullanmıştır. ${ }^{45}$

Diğer yandan aşı karşıtı tutumların bir başka nedeni de aşıların kısırlığa yol açtığı iddiasıdır. Aslında bu iddia dinî olmaktan çok siyasî/ideolojik bir temele dayanmakta olup oldukça eski ve daha ziyade Orta Doğu ve Afrika'daki Müslüman ülkelerden kaynaklanan bir iddiadır. Bu iddia; çoğunlukla aşı üreten firmaların batı (sıklıkla Avrupa ve Amerika) kökenli olduğundan yola çıkarak aşıların aslında Müslüman ya da Afrika ülkelerindeki nüfus artışını engelleme amaçlı kullanıldığını iddia etmektedir. Bu bağlamda temelinin herhangi bir tıbbî çalışmaya dayanmadığı, çoğunlukla siyasî bir komplo teorisi olarak görüldügü ifade edilmiştir. ${ }^{46}$ Buna rağmen bazı Müslüman ülkelerdeki aşılama faaliyetlerini olumsuz etkilemiştir. Örneğin 2008-2009 yıllarında bazı Müslüman grupların dinî muhalefeti Nijerya, Pakistan ve Afganistan'da çocuk felcine karşı bağışıklama programlarının başarısızlığında önemli bir faktör olmuştur. Pakistan'ın kimi bölgelerinde yaşanan bu dinî çatışma, etkili çocuk felci aşısının önündeki en büyük engellerden biri olmuştur. Zira Tâlibân, aşılamayı Müslüman nüfusu kısırlaştırmaya yönelik bir Amerikan hilesi olarak kınayan fetvalar yayınlamıştır. Nijerya ve Afganistan'daki aşı kampanyaları da özellikle 2003 yılında Nijerya'nın Kano eyaletinde radikal İslâmcı gruplar tarafından engellenmiş ve bu da enfeksiyonun Afrika'da daha önce çocuk felcinden arındırılmış 8 ülkeye geri dönmesine neden olmuştur. Nihayetinde Nijerya hükümeti bölgelerinde kullanılacak çocuk felci aşılarının kalite kontrol testlerini gözlemlemek için Güney Afrika, Endonezya ve Hindistan'a dinî temsilciler göndermiş ve ardından aşıyı güvendikleri üreticilerden temin etmiştir. ${ }^{47}$

\section{Sonuç}

Aşılara karşı olumsuz tutumlar aşının tarihi kadar eski olup çok boyutlu ve dinamik bir görünüm arz etmektedir. Sosyolojik açıdan bakıldığında durumun toplumsal güven algısı ile doğrudan bağlantılı olduğu söylenebilir. Zira toplumdaki algıları, tutumları ve bireysel davranışları etkileyen en önemli faktörlerden biri insanların belirli bir kuruma ya da kişiye karşı duyduğu güven düzeyidir. Eğer toplumsal kurumlar inandırıcılıklarını yitirmişse -tıpkı Orta çağda Reform hareketleriyle birlikte Katolik Kilisesinin yaşadığı durum gibi- o

Ömer Ataç-Alp Aker, "Aşı Karşıtlığı", Sağlık Düşüncesi ve Tıp Kültürü Dergisi 30 (2014), 45.

Yiğit vd., "Așı Karșıtlığı ve Fikri Gelișimi", 1258.

Kader, "Așı Karșıtlığı: Așı Kararsızlığı ve Așı Reddi", 385.

Haider J. Warraich, "Religious Opposition to Polio Vaccination", Emerging Infectious Disease journal 15/6 (2009); Grabenstein, "What the World's Religions Teach, Applied to Vaccines and Immune Globulins". 
kurumun toplum nezdindeki etkisi giderek azalacak demektir. Bugün gelinen noktada toplumun gerek aşılama faaliyetlerine gerekse aşıların içeriğine yönelik şüpheyle yaklaşmaları aslında sağlık/tıp kurumuna duyulan güven eksikliğinin bir yansımasıdır. Bu güvensizliğin altında yatan en önemli faktör ise modern tıbbın ilaç endüstrisi ile iç içe geçmiş olmasıdır. Başka bir deyişle insan sağlığının metalaştırılarak en temel insan hakkı olan yaşama hakkının kâr amacıyla araçsallaştırılmasıdır. Buna ek olarak özellikle son otuz yılda toplumsal hayatın giderek tıbbîleştirilmesi de aşı karşıtı tutumların yaygınlaşmasında etkili olmuștur.

Aşılamaya yönelik dinî temelli tepkiler aşıların keşfedilmesiyle eş zamanlı olarak ortaya çıkmıştır. İlk zamanlarda itirazlar teolojik temellere dayandırılsa da sonraki dönemlerde bu itirazlar aşıların içeriğinde kullanılan maddelere yönelmiştir. Dinî metinler ya da kurumlar tedaviye karşı olumlu yaklaşsa da dinen sakıncalı kabul edilen maddelerin aşı içeriğinde yer alması tereddüt yaşanmasına neden olmuştur. Buna ek olarak özellikle İ́slâm coğrafyasında radikal gruplar tarafından dile getirilen siyasî/ideolojik itirazlar çok daha kadim bir çatıșmanın dıșa vurumu olarak görülebilir. Zira temelde İslâm ve Batı medeniyetleri arasındaki tarihsel çekişme bugün Batı'nın öncülüğünde gelişen modern tıbba ve ürettiği tedavi araçlarına karşı refleksif bir tepki olarak açığa çıkmaktadır.

Finansman / Funding:

This research received no external funding. / Bu araştırma herhangi bir dış fon almamiștır.

Çıkar Çatışması / Conflicts of Interest:

The author declare no conflict of interest. / Yazar, herhangi bir çıkar çatıșması olmadığını beyan eder. 


\section{Kaynakça}

Aker, Ahmet Alp. "Aşı Karşıtlığı". Toplum ve Hekim 33/3 (Mayıs-Haziran 2018), 175-186.

Argüt, Neslihan - Yetim, Aylin ve Gökçay, Gülbin. "Aşı Kabulünü Etkileyen Faktörler". Çocuk Dergisi 16/1-2 (2016), 16-24. https://doi.org/doi:10.5222/j.child.2016.016

Ataç, Ömer - Aker, Alp. "Așı Karşıtlığı". Sağlık Düşüncesi ve Tıp Kültürü Dergisi 30 (2014), 42-47.

Aygün, Erhan - Tortop, Hasan Said. "Ebeveynlerin Așı Tereddüt Düzeylerinin ve Karşıtllk Nedenlerinin İncelenmesi". Güncel Pediatri 18/3 (2020), 300-316.

Badur, Selim. "Aşı Karşıtı Gruplar ve Aşılara Karşı Yapılan Haksız Suçlamalar". ANKEM Dergisi 25 (2011), 82-86.

Bekis Bozkurt, Hayrunnisa. "Așı Reddine Genel Bir Bakış ve Literatürün Gözden Geçirilmesi". Kafkas Tip Bilimleri Dergisi 8/1 (2018), 71-76. https://doi.org/10.5505/kjms.2018.12754

Boom, Julie A.-Cunningham, Rachel M. Understanding and Managing Vaccine Concerns. Switzerland: Springer, 2014.

Byström, Emma vd. "Confidence in the National Immunization Program among Parents in Sweden 2016 - A cross-Sectional Survey". Vaccine 38/22 (2020), 3909-3917. https://doi.org/10.1016/j.vaccine.2020.01.078

Chang, Kyujin-Lee, Soon Young. "Why Do Some Korean Parents Hesitate to Vaccinate Their Children?". Epidemiology and Health 41 (2019), 1-10. https://doi.org/10.4178/epih.e2019031

Demir, Talip. "Tıbbın Kestiği Parmak Acımaz: Seküler Tıbbın Kutsallaşması". Bozok Üniversitesi Illahiyat Fakültesi Dergisi [BOZIFDER] 14/14 (2018), 391-412.

Demir, Talip. Din ve Tıp: Sekülerleşme Perspektifinden Bir Yaklaşım. İstanbul: Muhayyel Yayıncılık, 2020.

Dubé, E. "Addressing Vaccine Hesitancy: The Crucial Role of Healthcare Providers". Clinical Microbiology and Infection 23/5 (2017), 279-280. https://doi.org/10.1016/j.cmi.2016.11.007

Dubé, Eve - Vivion, Maryline - MacDonald, Noni E. "Vaccine Hesitancy, Vaccine Refusal and the AntiVaccine Movement: Influence, İmpact and Implications". Expert Review of Vaccines 14/1 (2015), 99-117. https://doi.org/10.1586/14760584.2015.964212

Dubé, Eve vd. "Vaccine Hesitancy: An Overview". Human vaccines \& immunotherapeutics 9/8 (2013), 1763-1773. https://doi.org/10.4161/hv.24657

Fitzpatrick, Michael. "The Cutter Incident: How America's First Polio Vaccine Led to a Growing Vaccine Crisis". Journal of the Royal Society of Medicine 99/3 (2006), 156-156.

Grabenstein, John D. "What the World's Religions Teach, Applied to Vaccines and Immune Globulins". Vaccine 31/16 (2013), 2011-2023. https://doi.org/10.1016/j.vaccine.2013.02.026

Hasar, Muhammet, Özer, Z. Yelda-Bozdemir, Nafiz. "Așı Reddi Nedenleri ve Așllar Hakkındaki Görüșler". Cukurova Medical Journal 46/1 (2021), 166-176.

Hürriyet Gazetesi. "İkiz bebeklerine așı yaptırmayan savcının hukuk zaferi". Erișim 28 Kasım 2021. https://www.hurriyet.com.tr/kelebek/saglik/ikiz-bebeklerine-asi-yaptirmayan-savcininhukuk-zaferi-29343111

Kader, Çiğdem. "Așı Karşıtlığı: Așı Kararsızlığı ve Așı Reddi". ESTÜDAM Halk Sağlığı Dergisi 4/3 (2019), 377-388. https://doi.org/10.35232/estudamhsd.590304

Karafillakis, Emilie - Larson, Heidi J. "The Benefit of the Doubt or Doubts Over Benefits? A Systematic Literature Review of Perceived Risks of Vaccines in European Populations". Vaccine 35/37 (2017), 4840-4850. https://doi.org/10.1016/j.vaccine.2017.07.061

Karafillakis, Emilie vd. "Vaccine Hesitancy Among Healthcare Workers in Europe: A Qualitative Study". Vaccine 34/41 (2016), 5013-5020. https://doi.org/10.1016/j.vaccine.2016.08.029

Kata, Anna. "Anti-Vaccine Activists, Web 2.0, and the Postmodern Paradigm - An Overview of Tactics and Tropes Used Online by the Anti-Vaccination Movement". Vaccine 30/25 (2012), 37783789. https://doi.org/10.1016/j.vaccine.2011.11.112

Kestenbaum, Lori A.-Feemster, Kristen A. "Identifying and Addressing Vaccine Hesitancy". Pediatric Annals 44/4 (2015), 71-75. https://doi.org/10.3928/00904481-20150410-07

Kılıçaslan, Önder. "Așı Karşıtlığı Tarihçesi". Güncel Çocuk Sağlı̆̆ı ve Hastalıkları. ed. Cengiz Yakıncı. 25-41. Ankara: Akademisyen Yayınevi, 2020.

Kolodziejski, Lauren R. "Harms of Hedging in Scientific Discourse: Andrew Wakefield and the Origins of the Autism Vaccine Controversy". Technical Communication Quarterly 23/3 (2014), 165183. https://doi.org/10.1080/10572252.2013.816487

MacDonald, Noni E. "Vaccine Hesitancy: Definition, Scope and Determinants". Vaccine 33/34 (2015), 4161-4164. https://doi.org/10.1016/j.vaccine.2015.04.036 
Özceylan, Gökmen - Toprak, Dilek - Esen, Elif Serap. "Vaccine Rejection and Hesitation in Turkey". Human Vaccines \& Immunotherapeutics 16/5 (2020), 1034-1039. https://doi.org/10.1080/21645515.2020.1717182

Plotkin, Stanley A.-Plotkin, Susan L. "The Development of Vaccines: How the Past Led to the Future". Nature Reviews Microbiology 9/12 (2011), 889-893. https://doi.org/10.1038/nrmicro2668

Repalust, Anja - Šević, S. Rihtar ve S.-Štulhofer, A. "Childhood Vaccine Refusal and Hesitancy Intentions in Croatia: Insights from a Population-Based Study". Psychol Health \& Medicine 22/9 (2017), 1045-1055. https://doi.org/10.1080/13548506.2016.1263756

Sezgin, Deniz. Tıbbileștirilen Yașam Bireyselleștirilen Sağlık. İstanbul: Ayrıntı Yayınları, 2011.

Sofuoğlu Kılıç, Nilgün. "Post-Truth Çağda Așı Karşıtlığı". Türk İslâm Medeniyeti Akademik Araştırmalar Dergisi 16/31 (Şubat 2021), 99-117.

Spier, R. E. "Perception of Risk of Vaccine Adverse Events: A Historical Perspective". Vaccine 20 (2002), 78-84. https://doi.org/10.1016/S0264-410X(01)00306-1

Succi, Regina Célia de Menezes. "Vaccine Refusal - What We Need to Know". Jornal de Pediatria 94/6 (2018), 574-581. https://doi.org/10.1016/j.jped.2018.01.008

Taylor, Sebastian vd. "Understanding Vaccine Hesitancy in Polio Eradication in Northern Nigeria". Vaccine 35/47 (2017), 6438-6443. https://doi.org/10.1016/j.vaccine.2017.09.075

Toraman, Aynur-Erdem, Ramazan. "Kavramsal Açıdan Tıbbileştirme". Hacettepe Sağllk İdaresi Dergisi 19/4 (Aralık 2016), 423-442.

Warraich, Haider J. "Religious Opposition to Polio Vaccination". Emerging Infectious Disease journal 15/6 (2009), 978. https://doi.org/10.3201/eid1506.090087

Williamson, Stanley. "Anti-Vaccination Leagues". Archives of Disease in Childhood 59 (1984), 11951196.

Wolfe, Robert M.-Sharp, Lisa K. "Anti-vaccinationists: Past and Present". BMJ (Clinical research ed.) 325/7361 (2002), 430-432. https://doi.org/10.1136/bmj.325.7361.430

Wombwell, Eric vd. "Religious Barriers to Measles Vaccination". Journal of Community Health 40/3 (2015), 597-604. https://doi.org/10.1007/s10900-014-9956-1

Yaqub, Ohid vd. "Attitudes to Vaccination: A Critical Review". Social Science \& Medicine 112/(2014), 1-11. https://doi.org/10.1016/j.socscimed.2014.04.018

Yavuz, Melike. "Așı Karșitlığının Tarihçesi". Toplum ve Hekim 33/3 (Mayıs-Haziran 2018), 187-194.

Yiğit, Talip vd. "Așı Karșıtllı̆̆ ve Fikri Gelișimi". International Journal of Social Humanities Sciences Research (JSHSR) 7/53 (2020), 1244-1261. https://doi.org/10.26450/jshsr.1881

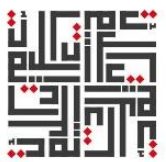

